\title{
EFFECT OF GENETIC GROUP, SEMEN DILUENTS AND FREEZING REGIMENS ON SPERM FREEZABILITY AND GOATS REPRODUCTIVITY
}

\author{
K.M. MOHAMMED*; M.H. KHALIL ${ }^{* *}$ and A.M. AL-SAEF ${ }^{* * *}$ \\ Animal Reproduction Research Institute (ARRI), Giza, AL-Haram, Egypt, P.O. 12556 \\ ****aculty of Agriculture, Benha University, Moshtohor, zip code 13736 Kalyoubia, Egypt \\ **** College of Agriculture \& Veterinary Medicine, Qassim University, Saudi Arabia \\ Correspondence email: $\underline{\text { kamel14@ hotmail.com }}$
}

Received at: 11/8/2012

Accepted: 10/11/2012

\section{ABSTRACT}

Two experiments were designed to study the effect of bucks breeds, semen extenders and freezing regimens on post-thaw semen motility and viability index (experiment 1). In experiment 2, semen diluents effects on reproductive performance was conducted. Semen was collected from Aradi (A), Damascuss (D) and cross $\left(1 / 2 \mathrm{~A}^{1} / 2 \mathrm{D}\right)$ bucks breeds. Good quality semen was divided into 4 portions, each diluted with one diluent (Milk, Na. Citrate, Tris and Na. Bicarbonate). The diluted semen was packaged into $0.5 \mathrm{ml}$ straws then cooled to $5^{\circ} \mathrm{C}$. After equilibration, half of the packaged straws were suspended $15 \mathrm{~cm}$ above liquid nitrogen (LN) for $15 \mathrm{~min}$. (Freezing regimen1; slow). Other half of straws was suspended at height 15 and $5 \mathrm{~cm}$ of LN for 10 and $5 \mathrm{~min}$, respectively (Freezing regimen2; rapid) before plunged into LN. Frozen semen was thawed for post-thaw motility and viability. In the second experiment, semen with good quality was extended with three types of extenders (Milk, Na. Citrate and Tris). Diluted semen were cooled to $5^{\circ} \mathrm{C}$ and used for AI. Results revealed that, pre-freeze semen motility was significant higher in Tris, Na. Citrate and Na. Bicarbonate than milk diluent. Post-thaw semen motility and viability were highly significant for milk and Na. Citrate than Tris and Na. Bicarbonate diluents. Post-thaw semen motility was significantly higher in Aradi and Damascus than crossbred. Post-thaw semen motility and viability revealed, significant higher means for Freezing regimen 2 than regimen 1. Milk and Tris diluents were significantly higher than Na. Citrate for fertility, fecundity and prolificacy. Aradi does was higher than Damascus does in fertility, fecundity and prolificacy. Also, Aradi does was significantly higher than $1 / 2 \mathrm{~A} 1 / 2 \mathrm{D}$ does in fertility, while the reverse trend was observed in fecundity and prolificacy. It was concluded that, regarding to post-thaw semen motility, semen viability, fertility $\%$, fecundity $\%$ and prolificacy $\%$, milk diluent is preferable than Tris and Na. citrate. Fertility rate of Aradi goat breed is higher than Damascus and crossbred $\left(1 / 2 \mathrm{~A}^{1} / 2 \mathrm{D}\right)$.

Keywords: Buck; doe; genetic groups; semen diluents; semen freezing; artificial insemination; reproductive performance.

\section{INTRODUCTION}

Successful AI needs good heat detection and semen handling. Artificial insemination (AI) has the greatest contribution in genetic improvement programs, mainly due to well-established methods for identifying males with the highest genetic merit (Evans and Maxwell, 1987; Leboeuf et al., 2000). The success of AI is based on the ability of collecting and cryopreserving spermatozoa efficiently from proven bucks to be used for inseminating the does over generations (Amoah and Gelaye, 1990). There are three methods of semen preservation (fresh, refrigerated and frozen) to be used worldwide in goats (Evans and Maxwell, 1987; Leboeuf et al., 2000). Spermatozoa are likely to suffer from considerable damages and deteriorations during dilution and preservation at low temperature. Therefore, using suitable diluents are basic necessities to have successful preservation of spermatozoa and higher conception rate in breeding programs (Salamon and Maxwell, 1995).

The main problem of worldwide development of AI in goats is related to the use of frozen semen, since the freezing process reduces the viability of sperm cells (Ritar, 1993; Ritar and Ball, 1993). Tris diluent 
was found to maintain higher quality of semen in prefreezing and post-thawing (Drobnis et al., 1980; Deka and Rao, 1987; Chauhan and Anand, 1990; Tuli and Holtz, 1992). Also, Singh and Purbey (1996) reported that Tris diluter was superior for semen freezing in goats than citrate diluter concerning post-thaw motility. On the contrary, Salvador et al. (2007) cited that milk diluent provided higher viability of spermatozoa than semen diluted in Tris and citrate. The present study aimed to investigate the effect of semen extenders, freezing regimens and genetic groups of bucks on post-thaw semen motility and viability index (experiment 1) and to verify that semen diluents could influence reproductive performance of does in arid environment (experiment 2).

\section{MATERIALS and METHODS}

\section{Study area:}

A crossbreeding program between Saudi Aradi goats (A) and Damascus goats (D) was carried out at Camel and Range Research Center in Al-Jouf province (Northern region of Saudi Arabia located at latitude of $29^{\circ} 58^{\prime} 11^{\prime \prime} \mathrm{N} 40^{\circ} 12^{\prime} 00^{\prime \prime} \mathrm{E}$ and longitude of $40.21^{\circ} \mathrm{W}$ and at $684 \mathrm{~m}$ above sea level). The hottest month of the year is August with an average high and low temperature of $41^{\circ} \mathrm{C}$ and $25^{\circ} \mathrm{C}$, respectively, whereas January is the coldest month of the year, with an average high and low temperature of $15^{\circ} \mathrm{C}$ and $4^{\circ} \mathrm{C}$, respectively. The annual rainfall ranges from 0 to $3 \mathrm{~mm}$.

\section{Animals management:}

This program permitted to produce three genetic groups of Aradi (A), Damascus (D) and crossbred $\left(1 / 2 \mathrm{~A}^{1} \frac{1}{2} \mathrm{D}\right)$ goats. Animals were housed in semishaded/open front barn and fed commercial concentrate and alfalfa hay. The amount of concentrate and hay were calculated according to the nutritional requirements for goats (Kids, does and bucks) depending on the animal ages and production status (National Research Council; NRC, 1981). Water, straw, salt and minerals supplemented in blocks were freely available to all animals.

\section{Experiment 1:}

This experiment was conducted to investigate the effect of semen extenders, freezing regimens and genetic groups of bucks on post-thaw semen motility and viability index. Twenty two bucks from three genetic groups of Aradi (A), Damascus (D) and cross $1 / 2 \mathrm{~A}^{1 / 2} \mathrm{D}$ were used in this study. Four semen diluents and two freezing programs were evaluated for freezing buck semen. Constituents of these diluents are shown in Table 1. Three to four ejaculates per buck were collected using artificial vagina. Semen samples with good motility of $\geq 70 \%$ were used for processing. Semen samples for each buck were divided into four portions, each portion was added to one diluent with dilution rate of 1:15-20 according to semen concentration. The diluted semen samples were packaged into $0.5 \mathrm{ml}$ straws at room temperature and arranged horizontally on freezing racks then gradually cooled to $5^{\circ} \mathrm{C}$ within $1-2 \mathrm{hrs}$ and placed in a refrigerator for equilibration. After equilibration time, half of the total packaged straws were suspended in liquid nitrogen $(\mathrm{LN})$ vapor inside a foam box container at height $15 \mathrm{~cm}$ above LN for 15 min (Freezing regimen 1; slow freezing). The other half of straws was suspended in LN vapor at height 15 then $5 \mathrm{~cm}$ of LN, for 10 then $5 \mathrm{~min}$ (Freezing regimen 2; rapid freezing) before plunged into $\mathrm{LN}$. Straws of frozen semen were stored in LN for 24-72 hrs before thawing. The frozen semen was thawed in a water bath at $37^{\circ} \mathrm{C}$ for $2-3$ minutes. Pre-freeze semen motility was recorded using microscope fitted with a biotherm stage $\left(37^{\circ} \mathrm{C}\right)$ and post-thaw motility at $0 \mathrm{hr}$ after thawing was reassessed after 1,2 and 3 hours of thermal stress and the viability index was determined for each semen sample.

\section{Experiment 2: \\ Semen preparation:}

In this experiment, estrus synchronization and AI were performed to 928 does. Semen samples were collected from genetically selected and improved bucks then extended using dilution rate of $1: 15$ to 1:20 (semen:diluent) according to sperm concentration to provide $120-150 \times 10^{6}$ as inseminated dose. Three types of extenders (skim milk, Na. Citrate and Tris) were used for semen dilution; constituents of the diluents are presented in Table 1. The diluted semen samples were gradually cooled within $2 \mathrm{hrs}$ to $5^{\circ} \mathrm{C}$ and stored in a refrigerator as chilled semen to be used for artificial insemination (Azawi et al., 1993).

\section{Does Preparation for AI:}

Intravaginal progestagen release device (CIDR) containing $300 \mathrm{mg}$ progesterone or intravaginal progesterone impregnated sponges containing 30 or $45 \mathrm{mg}$ fluorogesteone acetate (FGA) were taken to 928 does and maintained in situ for 15-17 days. At the day of sponge withdrawal, 200-300 IU/eCG was injected intramuscular. Artificial insemination (AI) was done blindly (irrespective to signs of estrus) 48 to 60 hours after sponge removal, using chilled diluted semen $\left(0.5 \mathrm{ml}\right.$ containing $120-150 \times 10^{6}$ motile spermatozoa) of the three types of diluents. AI was practiced using insemination pipette and vaginal speculum. The hind legs of the doe was lifted and placed at an angle of $45^{\circ}$ to the horizontal railing. The vaginal speculum was introduced into the vaginal passage and the cervix was localized with the help of light and by gentle sideways or downward manipulation of the speculum. Semen was deposited at a depth of $0.5-1.0 \mathrm{~cm}$ into the cervix (cervical insemination). Non returned rate (NRR) was applied 20 to 25 days after AI using vasectomized bucks to detect does not returned to estrus and confirmed at 30-45 days post insemination with the aid of 
ultrasound scanner. Parameters of reproductive performance involved in this study were: fertility rate (pregnant does/does inseminated)x100; kidding rate (kidded does/pregnant does)x100; fecundity rate (kids born /pregnant does)x100; and prolificacy rate (kids born /kidded does)x100.

\section{Statistical analysis:}

Data of semen and artificial insemination parameters and doe reproductive traits (fertility, kidding, fecundity, and prolificacy rates) were collected from 2006 to 2011. Such that were statistically analyzed using GLM procedures of SAS program (SAS, 1999). Data of post-thaw semen motility and viability were analyzed using the following linear model:

$$
\mathrm{y}=\mathrm{Xb}+\mathrm{e}
$$

Where $\mathbf{y}=$ vector of observed trait, $\mathbf{b}=$ vector of fixed effects (genetic group, semen diluents and freezing regimens); $\mathrm{X}$ is the incidence matrix relating records to the fixed effects; and $\mathbf{e}=$ vector of random error. Data of doe reproductive traits were analyzed using the same previous model after excluding the effect of freezing regimens.

\section{RESULTS}

\section{Effect of semen diluents on post-thaw semen viability}

As shown in Table 2, pre-freeze motility was the highest in semen $(\mathrm{P}<0.05)$ diluted with Tris extender (78.5), followed by sodium citrate (76.7), sodiumcitrate-bicarbonate diluents (76.1), and milk diluent (71.9). Post-thaw motility were significantly high $(\mathrm{P}<0.05)$ in semen diluted by milk diluent $(46.4)$, followed by sodium citrate (42.9), Tris (38.8) and sodium-citrate-bicarbonate diluents (35.8). The viability index of post-thaw semen motility was significantly high $(\mathrm{P}<0.05)$ in semen diluted by sodium citrate (104.2), descended by semen diluted in milk (103.5), Tris (95.1), and sodium-citratebicarbonate diluents (91.5).

\section{Effect of genetic group of bucks on post-thaw semen viability}

The mean values of pre-freezing semen motility for Aradi bucks (A), Damascus (D) and crossbred $\left(1 / 2 \mathrm{~A}^{1} / 2 \mathrm{D}\right)$ were $75.6,75.9$ and 76.5 , respectively, with no significant differences (Table 3 ). The same trends were observed for viability index where the mean values were 101.4, 95.5 and 93.5, for Aradi, Damascus and $1 / 2 \mathrm{~A}^{1} / 2 \mathrm{D}$ bucks, respectively, with no significant differences. Post-thaw semen motility at
Ohr were Significant higher $(\mathrm{P}<0.05)$ in Aradi (42.3) and Damascus (39.6) than cross bucks (38.1). Nonsignificant differences were observed among genetic groups in viability index of post-thaw semen motility.

\section{Effect of freezing regimens on post-thaw semen viability}

The effect of freezing protocols on post-thaw semen motility and viability index revealed that, the percentages of post-thaw semen motility (47.7 vs $34.1)$ and viability index (121.0 vs 76.3) were significantly higher $(\mathrm{P}<0.001)$ in rapid freezing regimen comparable to slow freezing regimen (Table 4).

\section{Effect of semen diluents on reproductive traits}

Regarding the effect of semen diluents on reproductive performance, the fertility rates were $52.99 \pm 3.27,45.83 \pm 5.91$ and $36.01 \pm 1.93$ for does inseminated by semen diluted with milk, Tris and sodium citrate respectively (Table 5). The corresponding percentages of kidding, fecundity, and prolificacy were $95.97 \pm 1.77, \quad 185.4 \pm 6.45$ and $193.28 \pm 5.69$ for does inseminated with milk diluent; $90.91 \pm 5.08,181.82 \pm 14.73$, and $200.00 \pm 11.74$ for Tris diluent; and $90.18 \pm 1.99, \quad 154.02 \pm 4.85$, and $170.79 \pm 3.84$ for Na. Citrate diluent, respectively. These results revealed that milk and Tris diluents were significantly higher in fertility, fecundity and prolificacy rates $(\mathrm{P}<0.05)$ than $\mathrm{Na}$. Citrate diluent, while the effect of diluent on kidding rate was nonsignificant (Table 5).

\section{Effect of genetic group on reproductive traits}

As shown in Table 6, local Aradi does was higher than Damascus does in fertility $(47.95 \pm 2.26$ vs $30.43 \pm 3.03)$, fecundity (164.96 \pm 4.87 vs $157.1 \pm 9.00)$ and prolificacy $(181.22 \pm 3.84$ vs $171.88 \pm 7.54)$. Also, Aradi does was significantly higher than $1 / 2 \mathrm{~A}^{1} / 2 \mathrm{D}$ does in fertility, while the reverse trend was observed in fecundity and prolificacy (Table 6). But, kidding rates were nearly similar in the three genetic groups studied.

\section{Interactions}

Interactions between diluents and genetic groups of bucks were significantly affected pre-freeze sperm motility, post-thaw motility and viability index $(\mathrm{P}<0.001)$. Also, the interactions between freezing regimens and diluents were significantly high on post-thaw semen motility and viability index $(\mathrm{P}<0.001)$. 
AssiutVet. Med. J. Vol. 58 No. 135 October 2012

Table 1: Composition of semen diluents ( $\mathrm{g} / 100 \mathrm{ml}$ distilled water)

\begin{tabular}{ccccc}
\hline Constituents $(\mathrm{gm})$ & \multicolumn{4}{c}{ Diluents } \\
\cline { 2 - 5 } & 1 & 2 & 3 & 4 \\
\hline Skimmed milk powder & 10 & - & - & 2.00 \\
\hline Na Citrate & - & 2.9 & - & - \\
\hline Tris & - & - & 3.786 & - \\
\hline Citric acid monohydrate & - & - & 2.172 & 0.21 \\
\hline Sodium bicarbonate & - & - & - & 0.04 \\
\hline KCl & - & - & - & 0.30 \\
\hline Glucose & - & - & 0.625 & $15 \%$ \\
\hline Egg yolk $(\mathrm{v} / \mathrm{v})$ & $15 \%$ & $15 \%$ & $15 \%$ & $7 \%$ \\
\hline Glycerol $(\mathrm{v} / \mathrm{v})$ & $7 \%$ & $7 \%$ & $7 \%$ & 50.000 \\
\hline Gentamycin $(\mu \mathrm{g})$ & 50.000 & 50.000 & 50.000 & 50.000 \\
\hline Tylosin $(\mu \mathrm{g})$ & 50.000 & 50.000 & 50.000 & 15.000
\end{tabular}

Table 2: Effect of semen diluents (Means \pm SE) on Pre-freezing and post-thaw semen motility and viability index

\begin{tabular}{|c|c|c|c|c|c|c|}
\hline \multirow{2}{*}{$\begin{array}{l}\text { Semen } \\
\text { diluent }\end{array}$} & \multirow{2}{*}{$\begin{array}{l}\text { Pre-freezing } \\
\text { motility }\end{array}$} & \multicolumn{5}{|c|}{ Post-thaw semen motility } \\
\hline & & Ohr & $1 \mathrm{hr}$ & $2 \mathrm{hrs}$ & $3 \mathrm{hrs}$ & Viability index \\
\hline Milk & $71.88 \pm 1.29^{b}$ & $46.44 \pm 1.29^{\mathrm{a}}$ & $39.36 \pm 1.29^{\mathrm{a}}$ & $31.08 \pm 1.27^{\mathrm{a}}$ & $19.64 \pm 1.18^{\mathrm{b}}$ & $103.48 \pm 3.38^{\mathrm{a}}$ \\
\hline $\mathrm{Na}$ citrate & $76.72 \pm 0.87^{\mathrm{a}}$ & $42.95 \pm 1.10^{\mathrm{a}}$ & $37.87 \pm 1.11^{\mathrm{a}}$ & $33.11 \pm 1.30^{\mathrm{a}}$ & $23.44 \pm 1.30^{\mathrm{ab}}$ & $104.18 \pm 3.13^{\mathrm{a}}$ \\
\hline Tris & $78.49 \pm 0.96^{\mathrm{a}}$ & $38.80 \pm 1.40^{\mathrm{b}}$ & $34.57 \pm 1.46^{\mathrm{ab}}$ & $29.07 \pm 1.45^{\mathrm{a}}$ & $25.12 \pm 1.43^{\mathrm{a}}$ & $95.06 \pm 4.06^{\mathrm{ab}}$ \\
\hline $\begin{array}{l}\mathrm{Na} \text { - citrate- } \\
\text { bicarbonate }\end{array}$ & $76.08 \pm 10.93^{\mathrm{a}}$ & $35.81 \pm 1.45^{\mathrm{b}}$ & $30.92 \pm 1.48^{\mathrm{b}}$ & $29.15 \pm 1.43^{\mathrm{a}}$ & $27.04 \pm 1.55^{\mathrm{a}}$ & $91.50 \pm 4.23^{\mathrm{b}}$ \\
\hline
\end{tabular}

Means in the same column with different superscripts are significantly differ at $\mathrm{P}<0.05$

Table 3: Effect of genetic groups of bucks (Means \pm SE) on pre-freezing and post-thaw semen motility and viability index

\begin{tabular}{lcccccc}
\hline \multirow{2}{*}{ Genetic group } & \multirow{2}{*}{$\begin{array}{c}\text { Pre-freezing } \\
\text { motility }\end{array}$} & $0 \mathrm{hr}$ & $1 \mathrm{hr}$ & $2 \mathrm{hrs}$ & $3 \mathrm{hrs}$ & Viability index \\
\cline { 3 - 7 } & $75.57 \pm 0.73^{\mathrm{a}}$ & $42.27 \pm 0.87^{\mathrm{a}}$ & $36.87 \pm 0.89^{\mathrm{a}}$ & $31.31 \pm 0.92^{\mathrm{a}}$ & $21.13 \pm 0.94^{\mathrm{a}}$ & $101.38 \pm 2.47^{\mathrm{a}}$ \\
\hline Aradi (A) & $75.91 \pm 0.84^{\mathrm{a}}$ & $39.65 \pm 1.30^{\mathrm{ab}}$ & $34.27 \pm 1.36^{\mathrm{a}}$ & $29.58 \pm 1.30^{\mathrm{a}}$ & $23.64 \pm 1.34^{\mathrm{a}}$ & $95.49 \pm 3.68^{\mathrm{a}}$ \\
\hline Damascus (D) & $76.55 \pm 1.35^{\mathrm{a}}$ & $38.11 \pm 1.71^{\mathrm{b}}$ & $33.31 \pm 1.77^{\mathrm{a}}$ & $29.53 \pm 1.73^{\mathrm{a}}$ & $23.18 \pm 1.71^{\mathrm{a}}$ & $93.48 \pm 4.74^{\mathrm{a}}$ \\
\hline $1 / 2 \mathrm{~A}^{1} / 2 \mathrm{D}$ & &
\end{tabular}

Means in the same column with different superscripts are significantly differ at $\mathrm{P}<0.05$.

Table 4: Effect of freezing regimens (Means \pm SE) on post-thaw semen motility and viability index

\begin{tabular}{|c|c|c|}
\hline \multirow{2}{*}{ Post-thaw hours } & \multicolumn{2}{|c|}{ Post-thaw semen motility } \\
\hline & Slow freezing regimen & Rapid freezing regimen \\
\hline $0 \mathrm{hr}$ & $34.15 \pm 1.04^{\mathrm{b}}$ & $47.74 \pm 0.66^{\mathrm{a}}$ \\
\hline $1 \mathrm{hr}$ & $28.54 \pm 1.00^{b}$ & $42.74 \pm 0.71^{\mathrm{a}}$ \\
\hline $2 \mathrm{hrs}$ & $22.60 \pm 0.93^{b}$ & $38.59 \pm 0.72^{a}$ \\
\hline $3 \mathrm{hrs}$ & $16.12 \pm 0.84^{b}$ & $31.65 \pm 0.88^{\mathrm{a}}$ \\
\hline Viability Index & $76.28 \pm 2.59^{b}$ & $121.03 \pm 1.89^{\mathrm{a}}$ \\
\hline
\end{tabular}

Means in the same row with different superscripts are significantly differ at $\mathrm{P}<0.001$. 
$\underline{\text { AssiutVet. Med. J. Vol. } 58 \text { No. } 135 \text { October } 2012}$

Table 5: Effect of semen diluents on doe reproductive performance

\begin{tabular}{lccccc}
\hline Diluent & $\begin{array}{c}\text { No. of } \\
\text { treated } \\
\text { does }\end{array}$ & Fertility $\%$ & Kidding $\%$ & Fecundity $\%$ & Prolificacy \% \\
\hline Milk & 234 & $52.99 \pm 3.27^{\mathrm{a}}$ & $95.97 \pm 1.77^{\mathrm{a}}$ & $185.48 \pm 6.45^{\mathrm{a}}$ & $193.28 \pm 5.69^{\mathrm{a}}$ \\
\hline Tris & 72 & $45.83 \pm 5.91^{\mathrm{ab}}$ & $90.91 \pm 5.08^{\mathrm{a}}$ & $181.82 \pm 14.73^{\mathrm{a}}$ & $200.00 \pm 11.74^{\mathrm{a}}$ \\
\hline Na Citrate & 622 & $36.01 \pm 1.93^{\mathrm{b}}$ & $90.18 \pm 1.99^{\mathrm{a}}$ & $154.02 \pm 4.85^{\mathrm{b}}$ & $170.79 \pm 3.84^{\mathrm{b}}$ \\
\hline
\end{tabular}

Means in the same columns with different superscripts are significantly differ at $\mathrm{P}<0.05$.

Table 6: Effect of genetic group on doe reproductive performance

\begin{tabular}{lccccc}
\hline Genetic group & $\begin{array}{c}\text { No. of } \\
\text { treated } \\
\text { does }\end{array}$ & Fertility $\%$ & Kidding $\%$ & Fecundity $\%$ & Prolificacy $\%$ \\
\hline Aradi (A) & 488 & $47.95 \pm 2.26^{\mathrm{a}}$ & $91.03 \pm 1.87^{\mathrm{a}}$ & $164.96 \pm 4.87^{\mathrm{ab}}$ & $181.22 \pm 3.84^{\mathrm{a}}$ \\
\hline Damascus (D) & 230 & $30.43 \pm 3.03^{\mathrm{b}}$ & $91.43 \pm 3.37^{\mathrm{a}}$ & $157.14 \pm 9.00^{\mathrm{c}}$ & $171.88 \pm 7.54^{\mathrm{a}}$ \\
\hline $1 / 2 \mathrm{~A} 1 / 2 \mathrm{D}$ & 210 & $36.67 \pm 3.33^{\mathrm{b}}$ & $96.10 \pm 2.22^{\mathrm{a}}$ & $180.52 \pm 8.48^{\mathrm{a}}$ & $187.84 \pm 7.69^{\mathrm{a}}$ \\
\hline
\end{tabular}

Means in the same columns with different superscripts are significantly differ at $\mathrm{P}<0.05$.

\section{DISCUSSION}

Cryopreservation of semen has become a valuable tool for the preservation of genetic reserves of endangered species or sires of superior breeding value (Sabine Schafer-Somi, et al., 2006). The results of this study have indicated that there is a difference between extenders regarding their pre-freeze motility, post-thaw motility and viability index of goat spermatozoa. Best results were obtained with a milk extender which appeared to provide higher in vitro spermatozoa viability. These findings are in harmony with those recorded by Salvador et al. (2007) who compared the effect of three extenders (skimmed milk, sodium Citrate and Tris-based diluents) on the in vitro viability of Murciano-Granadina goat spermatozoa stored at $5^{\circ} \mathrm{C}$. They stated that semen diluted by milk provided higher in vitro viability of spermatozoa than semen diluted in Tris. Hassan (1990); Mohammed et al. (1998) and Ziada et al. (1998) obtained satisfactory post-thaw motility by freezing buffalo semen in milk diluent more than that in Tris or sodium citrate diluents. Moreover, Dorado et al. (2007, 2010) observed that percentage of acrosome intact spermatozoa was significantly higher in semen samples diluted with milk extender than semen diluted by Tris extender, and at the same time semen cryopreserved in milk extender provided better pregnancy rates after insemination compared to those semen cryopreserved in Tris extender (52.4\% vs 42.9\%). Contrary, Chehadeh et al. (2001) observed that Tris was the best diluent for maintaining goat sperm motility $(77.1 \%)$ followed by milk (66.9\%), Cegly
$(66.0 \%)$ and sodium citrate $(64.0 \%)$ extenders. However, the post-thaw semen motility of milk diluent was sharply declined from 46.4 at $0 \mathrm{hr}$ to 19.6 at the third hour after thawing throughout the incubation period at $37^{\circ} \mathrm{C}$. This may be attributed to the rapid deterioration of buffering capacity of milk, to increased microbial growth and raising the acidity of the biological medium (Dhami and Sahni, 1995). Nunes et al. (1982) identified a protein (SBUIII) from the goat bulbourethral gland, which decreased survival of cooled or frozen goat sperm diluted in milk-based media. It also induced the acrosome reaction and subsequent cell death of spermatozoa incubated in milk medium at $37^{\circ} \mathrm{C}$ (Pellicer-Rubio et al., 1997). On the other hand, postthaw semen motility of Tris diluent herein was slowly decreased from 38.80 at $0 \mathrm{hr}$ to 25.1 at the third hour after thawing. Fischer (1990) and Shahram Bohlooli et al. (2012) found that Tris was the best in preserving acrosomal integrity and motility after thawing. Also, Dorado et al. (2007) detected that Tris extender provided more effective preservation of total motility, velocity parameters and amplitude of lateral head displacement after freezing than milk extender. Salamon and Ritar (1982) considered tris hydroxyl methyl aminomethane, which is an important component of Tris diluent, is principally responsible for prolonging the preservation time by creating a buffer zone in and outside of the spermatozoa. The fructose content of yolk Tris diluent may also help in maintaining the osmotic pressure, and providing nutrient for sperm metabolism.

Non-significant differences were observed among genetic groups in pre-freeze semen motility and post- 
thaw viability index. Similarly, William (1982) showed, the effects of age and goats breed on initial motility, Prefreeze motility and Post-thaw motility were negligible. Furstoss et al. (2009) evaluate the semen of 13151 and 9206 ejaculates of 758 Alpine and 535 Saanen bucks, respectively reporting that there is no significant effect for genetic groups of bucks on post-thaw semen motility. But, results herein showed significant differences in values $(\mathrm{P}<0.05)$ of post-thaw semen motility at $0 \mathrm{hr}$; being 42.3 for Aradi, 39.6 for Damascus and 38.1 for crossbred bucks of $1 / 2 \mathrm{~A}^{1} / 2 \mathrm{D}$. Similarly, Karatzas et al. (1997) using does of Greek breed (Capra prisca) that were synchronized and inseminated from bucks of Alpine, Saanen, and Damascus found that fertility and kidding rates were lower in does inseminated from semen of Damascus bucks than semen of Alpine and Saanen bucks.

In recent years, the development of freezing techniques for semen cryopreservation has become a major resource for the preservation of genetic material in most domestic species (Songsasen and Leibo 1997a,1997b; Ollero et al., 1998; Colenbrander et al., 2003; Cremades et al., 2005). Freezing and thawing rates have been shown to influence the postthaw survival of a number of cells including sperm cells from various species (Mazur, 1985 and Watson, 1990). In the present study, the effect of freezing protocols on post-thaw semen motility and viability index revealed that percentages of post-thaw motility and viability index were favorable $(\mathrm{P}<0.001)$ in rapid freezing regimen comparable to slow freezing regimen. These findings are in agreement with Mohammed et al. (1998) who recorded maximum post thaw motility of $63.3(\mathrm{P}<0.01)$ associated with the highest viability (153.3) when Friesian semen was rapidly frozen at $2 \mathrm{~cm}$ above $\mathrm{LN}$ for $15 \mathrm{~min}$. while the minimum motility (16.7) and the lowest viability index (44.2) were observed when the semen was relatively slow frozen at $8 \mathrm{~cm}$ above $\mathrm{LN}$ for $10 \mathrm{~min}$. The same authors added that the highest motility (63.3) of post-thaw buffalo semen $(\mathrm{P}<0.01)$ and the highest viability index (161.7) were obtained when the semen was frozen at $2 \mathrm{~cm}$ above $\mathrm{LN}$ for $10 \mathrm{~min}$, while the lowest motility and viability were obtained when the semen was frozen at $8 \mathrm{~cm}$ above $\mathrm{LN}$ for $10 \mathrm{~min}$. On the basis of post-thaw motility, Bhandari et al. (1982) reported that the fastest timing of freezing was the best for semen survival than slow freezing, which is in similar trend to our study. Contrary, Jansen (1989) reported that fast freezing (10 $\mathrm{min})$ gave low survival of sperm for cattle and buffalo semen where postthaw motility was 47.2 and 30.3 , respectively, while slow freezing (15 min) gave high survival of sperms where post-thaw motility was 57.2 and 34.3 for cattle and buffalo semen, respectively.

Interactions between genetic groups of bucks; freezing protocols on one side and semen diluents on the other side were significantly affects pre-freeze sperm motility, post-thaw motility and viability index $(\mathrm{P}<0.001)$. These findings are greatly in accordance with Mohammed et al. (1998) who found that interactions between freezing regimens and diluents were highly affected $(\mathrm{P}<0.01)$ viability index and AST of post-thaw buffalo spermatozoa. In opposition to our results, Dhami and Sahni (1995) and Mohammed et al. (1998) found non-significant interactions between diluents and cooling rates on post-thaw bovine semen motility and viability. However, the sperm cryosurvival appears to depend on biochemical composition of the diluents used, thermal behaviour, osmotic resistance and physical stresses determined by the freezing protocol (Hammerstedt et al., 1990; De Leeuw et al., 1991). Sperm survival in such conditions can be modified by the rate at which they are cooled (Fiser and Fairfull, 1990; Bwanga et al., 1991).

Also, the interactions between freezing regimens and diluents were significantly high on post-thaw semen motility and viability index $(\mathrm{P}<0.001)$. These findings are greatly in accordance with Mohammed et al. (1998) who found that interactions between freezing regimens and diluents were highly affected $(\mathrm{P}<0.01)$ viability index and AST of post-thaw buffalo spermatozoa. Contrary, Dhami and Sahni (1995) and Mohammed et al. (1998) found non-significant interactions between diluents and cooling rates on post-thaw bovine semen motility and viability.

Regarding the effect of semen diluents on reproductive performance, the results revealed that milk and Tris diluents were significantly higher $(\mathrm{P}<0.05)$ in fertility, fecundity and prolificacy rates than Na. Citrate diluent. These results are in accordance with those reported by Dorado et al. (2007, 2010), where Tris-glucose and skim milk extenders were used to compare the ability of extenders for maintaining the sperm viability after cryopreservation. They reported that Tris extender gave good in vitro performance compared to milk extender, although this improvement was not reflected in results of fertility rates, where semen cryopreserved in milk extender provided better pregnancy rates after intra-cervical insemination compared to those semen cryopreserved in Tris extender (52.4\% versus $42.9 \%$ ). Similarly, Mara et al. (2007) using three types of diluents for semen dilution reported that percentages of pregnant goats were $71.4,61.4$ and $48.8 \%$ for skim milk, tempol and tempol+hyaluronic acid diluents, respectively, while kidding rates were $66.7 \%$ for skim milk diluent, $61.4 \%$ for tempol diluent and $48.8 \%$ for tempol+HA diluent, without significant differences among treatment groups. Das et al. (1985) reported that conception rate of goat semen diluted and preserved in milk diluter was comparatively higher $(84 \%)$ than that of egg yolk citrate $(76 \%)$ and Tris diluter $(76$ $\%)$. In Norwegian dairy goat breed with applying AI for 514 does during natural oestrus, Nordstoga et al. 
(2010) found that spermatozoa diluted in milk extender resulted in a 25-day non-return rate (NRR) and kidding rates of $37.3 \%$ and $24.5 \%$, respectively, while semen diluted in Andromed diluent (commercial extender) resulted in $31.7 \%$ NRR and a kidding rate of $19.8 \%$.

The effect of genetic group on reproductive performance showed that, Aradi goat breed was higher than Damascus in fertility and fecundity. Also, Aradi goat breed was significantly higher $(\mathrm{P}<0.05)$ than crossbred $1 / 2 \mathrm{~A} 1 / 2 \mathrm{D}$ in fertility. In accordance with the present finding, Joshi and Shrestha (2003) found that the prolificacy rate of indigenous Khari breed was 1.97, while the crosses of Khari x Jamunapari, Khari x Barbari and Khari x Saanen were 1.79, 2.09 and 2.60 , respectively. It seems that the first cross $\left(1 / 2 \mathrm{~A}^{1} / 2 \mathrm{D}\right)$ showed higher values in fecundity, kidding and prolificacy, explaining the effect of heterosis. Similarly, Gaddour et al. (2007) recorded that local goat breed of southern Tunisia had higher rates than Damascus goat (used as ameliorative breed) in fertility (92.71 vs 95.00), prolificacy (153.43 vs 136.86) and fecundity (142.50 vs 129.71). Najari et al. (2002) concluded the same aspect for other goat breeds. Duricic et al. (2012) recorded that no significant differences between goat breeds for kidding and prolificacy rates were recorded.

In the present study, about $8 \%$ of the does not returned to estrus after 21-25 days of AI and recorded as pregnant didn't kidded as results of pseudopregnancy. High percentage of pseudopregnancy (9\%) was appeared in Aradi and Damascus goats, whereas a lower percentage was recorded in $1 / 2 \mathrm{~A} 1 / 2 \mathrm{D}$ doe $(4 \%)$. Similarly, pseudopregnancy appeared to be 3-20\% (Mialot et al., 1991; Hesselink 1993; Leboeuf et al., 1994). Pseudopregnancy was related to reproduction method (3.8\% in 1493 FGA/PMSG treated goats ys $2.5 \%$ in 3774 naturally mated goats, (Mialot et al. 1991), with parity ( $1 \%$ of nulliparous ys $18 \%$ of multiparous; Hesselink 1993), and with age (10\% of 280 less than 5 years old does vs $32 \%$ of 34 does more than 6 years old; Hesselink 1993).

\section{Conclusions}

Fertility and fecundity rates were significantly higher $(\mathrm{P}<0.05)$ in milk diluted semen than Tris and sodium citrate diluents although in vitro evaluation of prefreeze semen motility in milk diluent was significantly lower than $\mathrm{Na}$. citrate and Tris diluents. The cooling rate for semen should not be too fast to cause cell death due to cold shock or too slow to cause death due to osmotic shock. The first generation of crossing Damascus x Aradi showed high percentages of fertility, kidding, fecundity and prolificacy; indicating an important heterotic effect on these traits.

\section{Acknowledgement}

The authors greatly acknowledge King Abdulaziz City for Science and Technology, Saudi Arabia, that granted this project (No.: ARP: 24-22).

\section{REFERENCES}

Amoah, E.A. and Gelaye, S. (1990): Control of reproduction in the goat, 1992 . In: Gelaye, S., Amoah, E. A., Lilja, B. K. and Torando, B. (Ed.) Proc. Goat Production Symposium. pp. 51. Fort Valley, GA.

Azawi, O.I.; Al-Dahash, S.Y.A. and Juma, F.T. (1993): Effect of different diluents on Damascus goat semen. Small Ruminant Research, 9: 347-352.

Bhandari, N.; Chauhan, R. A. and Mathew, A. (1982): Note on the effect of freezing rate on the freezability of buffalo spermatozoa. Indian J. of Anim. Sci., 52: 1237-1238.

Bwanga, C.O.; Einarsson, S. and RodríguezMartínez, H. (1991): Cryopreservation of boar semen. II: Effect of cooling rate and duration of freezing point plateau on boar semen frozen in mini- and maxi-straws and plastic bags. Acta Veterinaria Scandinavica 32: 455-461.

Chauhan, M.S. and Anand, S.R. (1990): Effect of egg yolk lipids on the freezing of goat semen. Theriogenology, 34: 1003.

Chehadeh, R.Y.; ZIiada Maha, S.; Ghallab, A.M. and Seida, A.M. (2001): Freezabelity of Zaraibi goat semen in relation to different diluents, egg yolk concentrations and glycerol level. Egyptian Soc Anim. Reprod. Fert. Thirteenth Annual Congress. Giza 22-26 January.

Colenbrander, B.; Gadella, B.M. and Stout, T.A. (2003): The predictive value of semen analysis in the evaluation of stallion fertility. Reproduction in Domestic Animals 38: 305-311.

Cremades, T.; Roca J.; Rodriguez-Martinez, H.; Abaigar, T.; Vazquez, J.M. and Martinez, E.A. (2005): Kinematic changes during the cryopreservation of boar spermatozoa. Journal of Andrology, 26: 610-618.

Das, A.; Kakati, B.N.; Rajkonwar, C.K. and Borgohain, B.N. (1985): Survival of buck spermatozoa in egg yolk citrate, milk and tris diluters at $4^{\circ} \mathrm{C}$. Indian J. Anim. Sci., 55: 670.

De Leeuw, F.; Colenbrander, B. and Verkleij, A.J. (1991): The role membrane damage plays in cold shock and freezing injury. Reproduction in Domestic Animals, Supplement 1, 95-104.

Deka, B.C. and Rao, A. R. (1987): Effect of storage at $-1960 \mathrm{C}$ on quality of goat semen frozen with and without seminal plasma in Tris-based extender. Cherion, 16: 65.(A.B.A., vol.56, No.1487). 
Dhami, A.J. and Sahni, K.L. (1995): Deep-freezing of cattle and buffalo semen with or without equilibration and its fertility trails. A comparative study. Indian J. of Anim. Sci., 65(1): 59-64.

Dorado, I.; Rodríguez, M. and Hidalgo. (2007): Cryopreservation of goat spermatozoa: Comparison of two freezing extenders based on post-thaw sperm quality and fertility rates and artificial insemination. Theriogenology, 68: 168-177.

Dorado, J.; Munoz-Serrano, A. and Hidalgo, M. (2010): The effect of cryopreservation on goat semen characteristics related to sperm freezability. Animal Reproduction Science, 121(1-2): 115-23.

Drobnis, E.Z.; Nelson, E.A. and Burrill, M.J. (1980): Effect of survival processing variables on motility and glutamic oxaloacetic transaminase levels for frozen goat semen. III. Glycerol level. J. Anim. Sci., 51(suppl.I): 439 (Abstr).

Duricic, D.; Grizelj, J.; Dobranić, T.; Harapin, I.; Vince, S.; Kočila, P.; Folnožić, I.; Lipar, M.; Gračner, G.G. and Samardžija, M. (2012): Reproductive performance of boer goats in a moderate climate zone Veterinarski Arhiv 82 (4): 351-358.

Evans, G. and Maxwell, W.M.C. (1987): Salamon's artificial insemination of sheep and goats, Butterworths. $194 \mathrm{p}$.

Fischer, T. (1990): Computerized video micrography applied to deep-frozen ram semen, with reference to osmolarity of the diluent and morpohology of the spermatozoal head cap. Inaugural-Dissertation,

FachbereichVeterin" armedizin,

FreieUniversit”at, Berlin.A.B.A. No. 3712.

Fiser, P.S. and Fairfull, RW. (1990): Combined effect of glycerol concentration and cooling velocity on motility and acrosomal integrity of boar spermatozoa frozen in $0.5 \mathrm{ml}$ straws. Mol. Reprod. Dev. 25(2): 123-129.

Furstoss, V.; David, I.; Leboeuf, B.; Guillouet, P.; Boue, P. and Bodin, L. (2009): Genetic and non-genetic parameters of several characteristics of production and semen quality in young bucks. Anim. Reprod. Sci., 110 (1-2): 25-36.

Gaddour, A.; Najari, S.; Abdennebi, M. and Ouni, M. (2007): Reproductive performance and kid's mortality of pure breds and crossed caprine genotypes in the coastal Oases of southern Tunisia. Pakistan J. of Biol. Sci., 10(14): 23142319.

Hammerstedt, R. H. Graham, J. K. and Nolan, J. P. (1990). Cryopreservation of mammalian sperm: what we ask them to survive. Journal of Andrology, 11, 73-88.
Hassan, H.M. (1990): Effect of certain antibiotics on some bacteria isolated from contaminated buffalo semen. M.V.Sc. Thesis. Cairo Univ. Hesselink, J.W. (1993): Incidence of hydrometra in dairy goats. Vet. Rec., 132: 110-112.

Jansen, H. B. (1989): The influence of cooling rates practised in Netherlands on survival of bovine spermatozoa packaged in $0.25 \mathrm{ml}$ French straws. $11^{\text {th }}$ International Congress On Animal Reproduction and AI, Dublin, Ireland.

Joshi, B. R and Shrestha, B. S. (2003): The Goats. Their Production and Health Management. pp 11-18.

Karatzas, G.; Karagiannidis, A.; Varsakeli, S. and Brikas, P. (1997): Fertility of fresh and frozenthawed goat semen during the nonbreeding season. Theriogenology. $15: 1049-1059$.

Leboeuf, B.; Renaud, G.; De Fontaubert, Y.; Broqua, B. and Chemineau, P. (1994): Proceedings 7th International Meeting on Animal Reproduction MURCIA, 6-9 July · pp 251-255.

Leboeuf, B.; Restall, B. and Salomon, S. (2000): Production and storage of goat semen for artificial insemination. Anim. Reprod. Sci. 62, 113-141.

Mara, L.; Dattena, M.; Pilichi, S.; Sanna, D.; Branca, A. and Cappai, P. (2007): Effect of different diluents on goat semen fertility. Anim. Reprod. Sci. 102(1-2): 152-157.

Mazur, P. (1985): Basic concepts in freezing cells. In: Johnson, L.A, Larsson, K. (Eds.), Deep Freezing of Boar Semen. Swedish University of Agricultural Sciences, Uppsala, Sweden, pp. 91-111.

Mialot, J.P.; Saboureau, L.; Gueraud, J.M.; Prengere, E.; Parizot, D.; Pirot, G.; Duquesnel, R.; Petat, M. and Chemineau, P. (1991): Pseudopregnancy in goats. Rec. Med. Vet., Spec. Reprod. Rum., 1: 383-390.

Mohammed, K.M.; Ziada Maha, S. and Darwish, G.M. (1998): Assiut Vet. Med Practical trials for freezing semen of buffalo and friesian bulls: Effect of various regimens of freezing, different milk extenders and types of straws packages on post-thawing semen characters. J. 39 No. 77.

Najari, S.; Ben Hamouda, M. and Khaldi, G. (2002): Expression of the kid's genotypes in arid regions conditions. Elsen J.M. and Ducroq V. (Eds.) $7^{\text {th }}$ World congress on genetics applied to livestock production. Montpellier, France., 33: 401-404.

Nordstoga, A.B.; Soderquist, L.; Adnoy, T.; Farstad, W. and Paulenz, H. (2010): Vaginal deposition of frozen-thawed semen in Norwegian Dairy goats: comparison of single and double insemination with equal total number of spermatozoa. Theriogenology. 74(5): 895-900.

NRC. (1981): Nutrient Requirements of Goats. National Academy Press, Washington, DC. 
Nunes, J.F.; Corteel, J.M.; Combarnous, Y. and Baril, G. (1982): Role du plasma seminal dans la survie in vitro des spermatozo" 1 ds de bouc. Reprod. Nutr. D’ev. 22: 611-620.

Ollero, M.; Perez-Pe, R.; Muino-Blanco, T. and Cebrian-Perez, JA. (1998): Improvement of ram sperm cryopreservation protocols assessed by sperm quality parameters and heterogeneity analysis. Cryobiology. 37: 1-12.

Pellicer-Rubio, M.T.; Magallon, T. and Combarnous, Y. (1997): Deterioration of goat sperm viability in milk extenders is due to a bulbourethral 60 kilo Dalton glycoprotein with triglyceride lipase activity. Biol. Reprod. 57: 1023-1031.

Ritar, A.J. (1993): Control of ovulation, storage of semen, and artificial insemination of fibreproducing goats in Australia: A review. Aust. J. Exp. Agric., 33: 807-820.

Ritar, A.J. and Ball, P.D. (1993): The effect of freeze-thawing of goat and sheep semen at a high density of spermatozoa on cell viability and fertility after insemination. Animal Reproduction Science, 31: 249-262.

Sabine, S.; Silvia, K.; Elzbieta, K.; Dieter, K. and Christine, A. (2006): Effects of semen extender and semen processing on motility and viability of frozen thawed dog spermatozoa. Theriogenology. 66: 173-182.

Salamon, S. and Ritar, A.J. (1982): Deep freezing of Angora goat semen: effects of diluent composition, method and rate of dilution on survival of spermatozoa. Aust. J. Biol. Sci., 35: 295.

Salamon, S. and Maxwell, W.M.C. (1995): Frozen storage of ram semen. I. Processing, freezing, thawing and fertility after cervical insemination. Anim. Reprod. Sci., 37: 185.

Salvador, I. J.; Yaniz, E.A.; Gomez, M.A. and Silvestre (2007); Effect of different extenders and washing of seminal plasma on buck semen storage at $5^{\circ} \mathrm{C}$. Medwell Journals, 272-277.
SAS. (1999): SAS. Procedure Guide. Versin 6.12 Edition, SAS Institute, INC, Cary, NC, USA.

Shahram, B.; Fatin, C.; Jafar, P.J.; Sarain, R. and Şeyma, B. (2012): The Effect of Different Extenders on Post-thaw Sperm Viability, Motility and Membrane Integrity in cryopreserved semen of Zandi Ram. J. Basic. Appl. Sci. Res., 2(2)1120-1123.

Singh, L.P. and Purbey, L.N. (1996): Preservability of goat spermatozoa in tris and citrate extenders at -196C and 5C. Ind. J. Anim. Sci., 66: 1139.

Songsasen, N. and Leibo, S.P. (1997a): Cryopreservation of mouse spermatozoa. I. Effect of seeding on fertilizing ability of cryopreserved spermatozoa. Cryobiology, 35 : 240-254.

Songsasen, N. and Leibo, S.P. (1997b): Cryopreservation of mouse spermatozoa. II. Relationship between survival after cryopreservation and osmotic tolerance of spermatozoa from three strains of mice. Cryobiology, 35: 255-269.

Tuli, R.K. and Holtz, W. (1992): The effect of zwitterion buffers on the freezability of boer goat semen. Theriogenology, 37: 947.

Watson, P.F. (1990): Artificial insemination and the preservation of semen. In: Lamming, G.E. (Ed.), Marshall's Physiology of Reproduction, Churchill Livingstone, Oxford, pp. 747-869.

William, B.M. (1982): Effect of Age, Breed and Season on Semen Production, Freezability and Sexual Activity in Male Goats at puberty. MSc. Thesis (1982) California State Polytechnic University, Pomona, California, USA.

Ziada Maha, S.; Darwish, G.M. and Mohammed, K.M. (1998): Freezability of buffalo-semen concerning different diluents, freezing programs and thawing regimens. Alex. J. Vet. Sci., vol. 14, No. 3:85-103. 
تأثير المجموعات الوراثية ونوع المخفف ونظم التجميد على قابلية السائل المنوي للتجميد وكذلك الكفاءة التناسلية للماعز

$$
\text { كامل مصطفى السبي }
$$

الهاف من هذه الدراسة هو معرفة تأثير ممددات السائل المنوى وطرق تجميده وسلالة التيوس على حركة وحيوية الحيامن بعد التجميد والاسالة

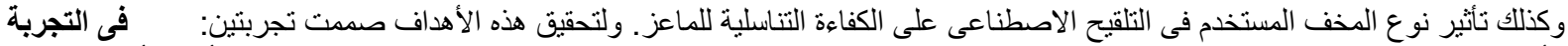

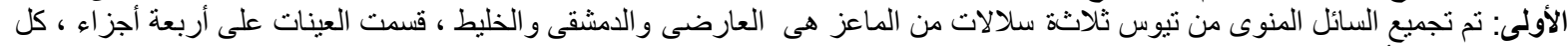

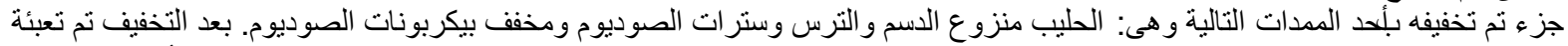

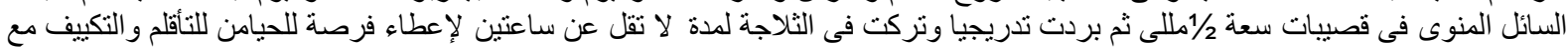

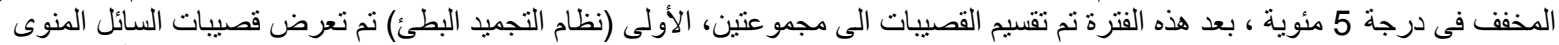

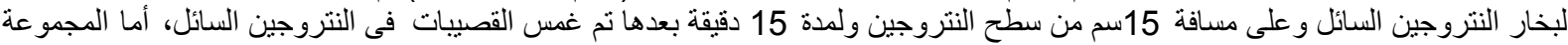

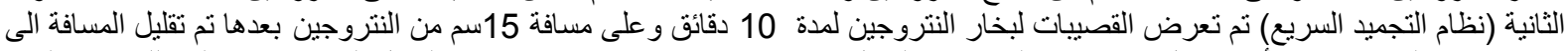

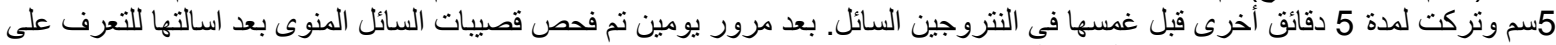

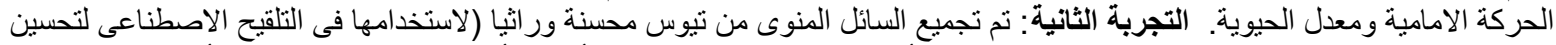

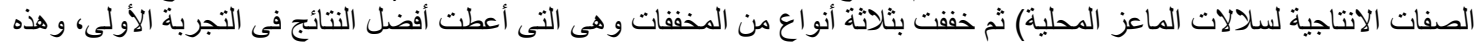

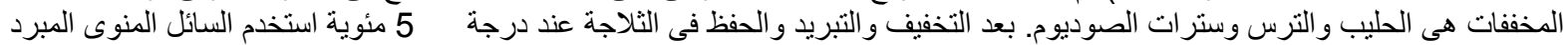

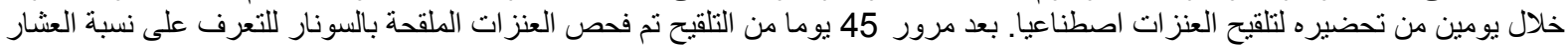

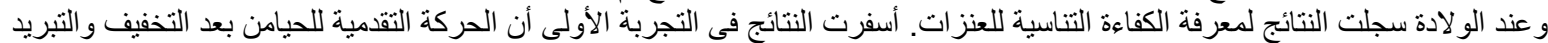

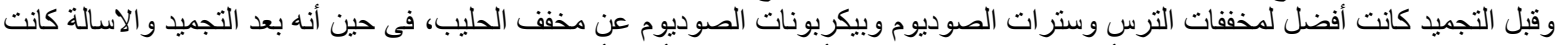

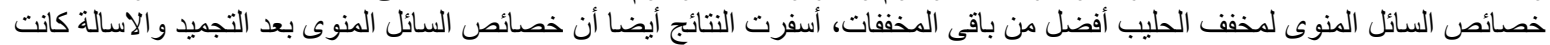

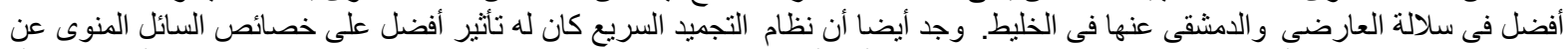

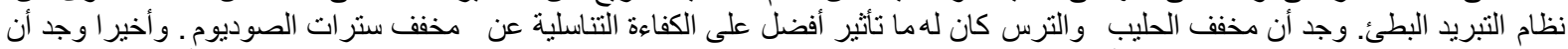

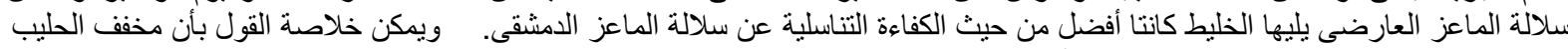

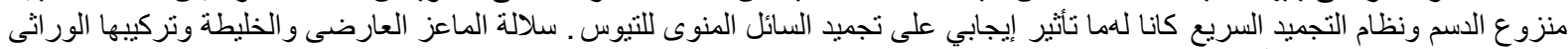
1/21/2 عارضى1/2 دمشقى كانتا أفضل من حيث الكفاءة التناسلية عن سلالة الماعز الدمشقى. 